\title{
PEMANFAATAN LIMBAH CAIR INDUSTRI PCB SEBAGAI LARUTAN ELEKTROLIT COPPER PLATING
}

\section{UTILIZATION OF PCB WASTEWATER INDUSTRIAL AS COPPER PLATING ELEKTROLITE}

\author{
Handaru Bowo Cahyono, Rieke Yuliastuti \\ Baristand Industri Surabaya, Kementerian Perindustrian R.I \\ Jl. Jagir Wonokromo 360, Surabaya \\ Email : riekeyuliastuti@yahoo.com
}

Diterima : 27-08-2019

Direvisi : 04-11-2019

Disetujui : 16-12-2019

\begin{abstract}
ABSTRAK
Limbah cair yang dihasilkan dari proses etching di industri Printed Circuit Board (PCB) masih mengandung banyak tembaga $(\mathrm{Cu})$. Tembaga $(\mathrm{Cu})$ merupakan salah satu logam yang sering digunakan sebagai bahan pelapis pada produk elektroplating. Melatarbelakangi hal tersebut maka dilakukan penelitian mengenai potensi kemampuan pelapisan tembaga menggunakan limbah cair etching industri PCB sebagai larutan elektrolit dengan benda kerja dari besi, tujuannya adalah limbah cair sisa proses etching PCB dapat termanfaatkan. Tipe larutan elektrolit yang digunakan adalah larutan tembaga non cyanide yaitu menggunakan Tembaga clorida $\left(\mathrm{CuCl}_{2}\right)$ sebagai pengganti tembaga sulfat $\left(\mathrm{CuSO}_{4}\right)$. Variabel penelitiannya adalah durasi plating selama 30 detik, 60 detik dan 90 detik dan penggunaan Asam sulfat sebesar $45 \mathrm{~g} / \mathrm{l} ; 67,5 \mathrm{~g} / \mathrm{l}$ dan $90 \mathrm{~g} / \mathrm{l}$. Dari hasil penelitian didapatkan data, hasil limbah cair proses etching PCB yang mengandung tembaga terlarut hingga $15 \%$ dapat digunakan sebagai larutan elektrolit pada proses pelapisan logam tembaga. Penambahan bobot lapisan tembaga pada benda kerja terjadi pada seluruh variabel perlakuan. Namun pada durasi plating 90 detik memberikan keretakan pada benda kerja. Warna lapisan tembaga yang dimunculkan untuk seluruh perlakuan dengan bahan limbah cair tidak secerah warna yang dimunculkan oleh larutan kontrol $\left(\mathrm{CuSO}_{4}\right)$. Hal tersebut dikarenakan impurities besi terlarut dalam limbah cair sekitar 138,65 mg/l sedangkan pada larutan kontrol (CuSO 4$)$ hanya mengandung besi terlarut hanya sebesar $0,445 \mathrm{mg} / \mathrm{L}$.
\end{abstract}

Kata kunci: limbah cair industri PCB, tembaga chlorida, plating, elektrolit, tembaga sulfat

\section{ABSTRACT}

Waste water generated from the etching process in the $P C B$ industry still contains a lot of copper (Cu). Copper (Cu) is a metal that is often used as a coating on electroplating products. Against this background, a study was conducted on the potential ability of copper coating using $P C B$ industrial etching liquid waste as an electrolyte solution with iron workpieces, so that the liquid waste from the PCB etching process can be utilized. The type of electrolyte solution used is a non cyanide copper solution which uses copper cloride subtitute of copper sulfate $\left(\mathrm{CuSO}_{4}\right)$. The research variables were plating duration for 30 seconds, 60 seconds and 90 seconds and the use of sulfuric acid was $45 \mathrm{~g} / \mathrm{l}, 67.5 \mathrm{~g} / \mathrm{I}$ and $90 \mathrm{~g} / \mathrm{l}$. From the research, the results of the PCB etching process containing $15 \%$ dissolved copper can be used as an electrolyte solution in the copper metal coating process. Addition of the weight of the copper layer to the workpiece occurs in all treatment variables. 
However, the plating duration of 90 seconds gives cracks to the workpiece. In all treatments, the colors that appear for all treatments are not as bright as the colors that are raised by the control (CuSO 4$)$. That is because the impurities of dissolved iron in liquid waste is around $138.65 \mathrm{mg} / \mathrm{l}$ whereas in the control solution (CuSO4) only contains dissolved iron of only $0.445 \mathrm{mg} / \mathrm{l}$.

Keywords: PCB wastewater industrial, copper chloride, plating, electrolite, copper sulfate

\section{PENDAHULUAN}

D apan PCB merupakan sebuah papan tipis yang terbuat dari sejenis fiber sebagai media isolasinya, yang digunakan sebagai tatakan komponen elektronika, yang di pasang dan di rangkai dimana salah satu sisinya dilapisi tembaga untuk menyolder kaki-kaki komponen elektronik (diode, kapasitor, dll.) (Ridho, 2014). Papan PCB memiliki jalur-jalur konduktor yang terbuat dari tembaga dan berfungsi sebagai penghubung antara satu komponen dengan komponen lainnya (Haughn, 2013).

Secara umum rangkaian proses pembuatan $\mathrm{PCB}$, merupakan kegiatan pengerjaan fisik terhadap lembaran papan PCB dengan cara memotong, membentuk/mencetak jalur pada permukaan PCB serta pengerjaan secara kimiawi antara lain pengikisan lapisan tembaga, pencucian dengan alkali, pembilasan serta proses pengeringan papan PCB (Luda, 2011).

Proses etching terhadap papan PCB adalah tahapan pengerjaan secara kimiawi dimana papan PCB akan direndam dalam larutan etching selama durasi waktu tertentu. Proses ini bertujuan untuk mengikis lapisan tembaga yang tidak dikehendaki dari permukaan papan PCB. Sedangkan untuk Durasi proses etching belum ada standard yang ditetapkan, hal tersebut karena tidak ada kesepakatan terkait bahan etching yang digunakan serta juga dipengaruhi oleh konsentrasi larutan etching yang selalu mengalami perubahan per satuan waktu. Pada umumnya larutan etching yang digunakan adalah larutan yang bersifat asam kuat dengan maksud agar durasi proses etching menjadi singkat. Myers Joshua, 2011 mengemukakan beberapa bahan kimia yang sering digunakan sebagai larutan etching antara lain adalah Sodium Persulfat $\left(\mathrm{Na}_{2} \mathrm{~S}_{2} \mathrm{O}_{8}\right)$ / Feri klorida $\left(\mathrm{FeCl}_{3}\right)$ / Amonium Persulfat / Asam klorida $(\mathrm{HCl})$. Larutan tersebut digunakan untuk merendam papan secara terus menerus hingga jenuh oleh tembaga terlarut.

Setelah larutan etching tidak lagi menunjukkan kemampuannya dalam 'mengikis' lapisan tembaga pada permukaan papan PCB karena jenuh, maka larutan tersebut akan dibuang sebagai limbah cair. Cahyono dan Mahmida, 2014 mengatakan bahwa karakteristik visual larutan limbah cair ini berwarna hijau pekat hingga kehitaman dan jika dilakukan pengenceran hingga beberapa kali maka larutan tampak berwarna biru kehijauan. Sifat dominan lainnya pada larutan ini adalah sangat korosif, merusak serta berbau tajam. Hasil pengujian terhadap limbah cair menunjukkan kandungan tembaga $(\mathrm{Cu})$ terlarut dalam limbah cair dapat mencapai kadar 13\% s/d 17\%. Anonim, 2012, bahkan mengatakan sekitar 1,5 s/d 3,5 L/m2 larutan etching dibuang oleh industri pengolahan papan PCB dengan kandungan tembaga terlarut sekitar 130 - $150 \mathrm{~g} / \mathrm{L}$. Sedangkan dalam teknik pelapisan tembaga yang disampaikan oleh Azhar (2011), untuk pelapisan bahan dengan tembaga pada industri elektroplating dibutuhkan tembaga sulfat sekitar 195-250 g/l dalam larutan elektrolitnya. Hal tersebut akan sangat disayangkan apabila kandungan tembaga terlarut dalam larutan etching terbuang sebagai limbah.

Lebih jauh Cahyono dan Mahmida, 2014 mengatakan bahwa kandungan logam dalam limbah cair sangat dipengaruhi oleh perilaku industri / pengguna karena pada umumnya industri akan memaksimalkan kemampuan larutan asam dalam mengikis lapisan 
tembaga pada papan PCB (proses etching) sehingga larutan limbah akan mengandung tembaga terlarut dalam jumlah yang sangat tinggi.

Cahyono dan Mahmida, 2014 juga mengatakan dari segi kuantitas limbah cair sisa proses etching sangat fluktuatif dan bergantung pada dua hal yaitu kapasitas produksi/order dan perilaku operator proses etching. Namun demikian tak kurang dari 3-4 kg tembaga terlarut terbuang bersama limbah cair pada setiap minggunya. Biaya yang tidak sedikit harus dikeluarkan industri PCB sebagai konsekwensi dihasilkannya limbah tersebut. Beberapa alternative pengelolaan limbah antara lain alih kelola pada pihak ke-3 maupun pengolahan limbah cair di IPAL yang disertai ijin pengelolaan limbah dengan hanya menghasilkan lumpur Tembaga hidroksida $\left(\mathrm{Cu}(\mathrm{OH})_{2}\right)$ yang kurang bermanfaat dan tetap menjadi urusan pihak ke-3.

Pelapisan logam dengan logam lainnya menggunakan prinsip elektrolisis telah lama dikenal dan diaplikasikan secara luas untuk berbagai keperluan. Lou dan Huang, 2006 mengatakan elektroplating adalah proses elektrodeposisi untuk menghasilkan lapisan padat, seragam, dan melekat, umumnya berasal dari logam atau paduan, pada permukaan benda kerja dengan bantuan arus listrik. Lebih jauh dia mengatakan bahwa penerapan paling umum kegiatan elektroplating adalah untuk keperluan dekoratif dan / atau tujuan perlindungan atau penambahan sifat spesifik dari permukaan. Permukaan ini dapat berupa konduktor seperti logam atau nonkonduktor seperti plastik. Produk electroplating telah dimanfaatkan pada mobil, kapal, pesawat udara, mesin, barang elektronik, perhiasan, industri pertahanan dan industri mainan. Logam pelapis dalam bentuk terlarut digunakan umumnya memiliki potensial elektroda lebih negative dari logam yang dilapis. Logam yang sering digunakan sebagai bahan pelapis benda kerja antara lain Zink (Zn), Krom (Cr), Magnesium (Mg), Nikel (Ni) dan Tembaga (Cu).

Pelapisan dengan logam tembaga (Cu) umumnya digunakan sebagai bahan lapisan dasar sebelum logam / benda kerja kembali dilapis dengan logam lain yang lebih berharga yaitu nikel dan krom. Aplikasi ini banyak digunakan untuk memenuhi kebutuhan dekoratif yang bernilai tinggi ataupun finishing pada produk-produk komponen listrik, otomotip, perhiasan dan sebagainya (Mustopo, 2011).

Sebagai lapisan dasar (strike) pada industri pelapisan / electroplating, logam tembaga telah dimanfaatkan secara luas utamanya untuk alasan menekan biaya produksi. Dikenal dua model larutan elektrolit pada proses pelapisan logam (electroplating) yaitu proses pelapisan dengan basis larutan elektrolit yang mengandung senyawa cyanide dan larutan elektrolit yang tidak mengandung senyawa cyanide (non cyanide solution). Kedua proses ini memiliki keunggulan dan kelemahan masing-masing, namun dewasa ini metoda pelapisan dengan larutan elektrolit menggunakan cyanide mulai dibatasi dan banyak dilakukan penelitian baru terkait substitusi maupun penghilangan cyanide sebagai larutan elektrolit, hal ini karena dampak negative yang ditimbulkan oleh limbah sisa proses yang mengandung cyanide sangat berbahaya baik bagi lingkungan maupun manusia.(freecyanide) (Purwanto,dkk 2017). Larutan elektrolit tembaga yang umum digunakan sebagai larutan elektrolit lapis tembaga dikenal dengan larutan tembaga asam konvensional dengan formula sebagai berikut : Copper Sulfat $\left(\mathrm{CuSO}_{4}\right) 195-250 \mathrm{gr} / \mathrm{L}$; Asam Sulfat $\left(\mathrm{H}_{2} \mathrm{SO}_{4}\right) 45$ $90 \mathrm{gr} / \mathrm{L}$; Asam Chlorida $(\mathrm{HCl}) 40-80 \mathrm{ml} / \mathrm{L}$; Kondisi Operasi : Temperatur $25-35{ }^{\circ} \mathrm{C}$; Agitasi ; Filterisasi ; pH 1 ; Voltase 2 - 9 volt. Produk logam lapis tembaga dari proses ini merupakan produk antara sebelum logam kembali dilapis dengan logam lain misalnya nikel dan krom (Azhar, 2011).

Maksud dari penelitian ini adalah mengetahui potensi kemampuan pelapisan tembaga pada benda kerja dari besi dengan limbah cair etching industri PCB sebagai larutan elektrolitnya. Tujuannya adalah untuk memanfaatkan limbah cair sisa proses etching PCB. 


\section{BAHAN DAN METODE}

\section{Bahan dan peralatan Penelitian}

Bahan yang digunakan pada penelitian ini adalah pelat logam besi yang akan digunakan sebagai benda kerja, larutan limbah cair yang diambil dari proses etching PCB, Asam Klorida teknis, Asam Sulfat teknis, Natrium Hidroksida teknis, Aquadest, Kertas gosok halus, pH kertas. Sedangkan peralatan yang digunakan adalah rectifier, beaker glass, kabel listrik (konduktor), gelas ukur, bak pencampur/penampung larutan elektrolit, peniris, oven pengering, neraca analytic.

\section{Prosedur Penelitian}

Penelitian dilakukan skala laboratorium, di laboratorium proses Balai Riset dan Standardisasi Industri Surabaya. Metode kerja penelitian terbagi atas beberapa tahapan yaitu uji karakteristik limbah cair sisa etching $\mathrm{PCB}$, proses penyiapan larutan elektrolit, penyiapan benda kerja, proses elektroplating dan analisa hasil elektroplating.

Langkah pertama adalah dilakukan pengujian limbah cair sisa etching PCB untuk mengetahui karakteristiknya. Parameter yang duji adalah tembaga (Cu), Seng (Zn), Krom ( $\mathrm{Cr})$, Timbal (Pb), Cadmium (Cd), Besi (Fe), TDS, Nikel (Ni), Densitas Cairan dan pH. Metode Uji yang dilakukan disesuaikan dengan standard pengujian masing-masing parameter berdasarkan Standard methods for the examination of Water and Wastewater $23^{\text {nd }}$ Edition Rice at al., 2017.

Pada penyiapan larutan elektrolit, terdapat 2 jenis larutan yang disiapkan yaitu larutan elektrolit Tembaga Sulfat $\left(\mathrm{CuSO}_{4}\right)$ teknis dan Penyiapan larutan elektrolit dari limbah cair sisa proses etching PCB. Larutan elektrolit Tembaga Sulfat $\left(\mathrm{CuSO}_{4}\right)$ adalah larutan yang digunakan sebagai kontrol/pembanding. Penyiapan larutan elektrolit ini meliputi formulasi, penimbangan, pelarutan, penyaringan, pengenceran, serta agitasi. Sedangkan Penyiapan larutan elektrolit dari limbah cair sisa proses etching PCB dibuat dengan larutan limbah cair dengan kepekatan sekitar $15 \% \mathrm{Cu}$. Penyiapan larutan elektrolit ini meliputi penyaringan, formulasi, penimbangan, pengenceran dan serta agitasi.

Sebagai basis hitung kadar tembaga terlarut dalam penelitian ini mengacu pada referensi Azhar (2011) dalam Modul Diklat : Teknik Pelapisan Tembaga yang mengatakan bahwa untuk larutan tembaga asam konvensional digunakan formulasi dengan konsentrasi tembaga sebagai $\mathrm{CuSO}_{4}$ berkisar antara 195 s/d $250 \mathrm{gr} / \mathrm{L}$. Sehingga dari perhitungan teoritis kadar Cu dalam larutan elektrolit kontrol dan limbah cair dibuat sama yaitu kisaran $88,58 \mathrm{gr} / \mathrm{L}$.

Dalam penelitian ini larutan tembaga asam konvensional yang digunakan sebagai larutan kontrol memiliki formulasi sebagai berikut : Copper Sulfat $\left(\mathrm{CuSO}_{4}\right)$ 222,5 gr/L (fraksi massa $\mathrm{Cu}$ sekitar 88,58 gram) ; sementara penggunaan Asam Sulfat $\left(\mathrm{H}_{2} \mathrm{SO}_{4}\right)$ diberikan bervariasi yaitu : $45 \mathrm{gr} / \mathrm{L}$ (kontrol A) ; 67,5 gr/L (kontrol B) ; $90 \mathrm{gr} / \mathrm{L}$ (kontrol C) ; Asam Chlorida $(\mathrm{HCl}) 60 \mathrm{ml} / \mathrm{L}$; Kondisi Operasi : Temperatur 25 - $35{ }^{\circ} \mathrm{C}$; Agitasi (pengadukan) ; Filterisasi ; $\mathrm{pH} 1$; Voltase 7 volt.

Sedangkan untuk larutan limbah cair sisa proses etching yang digunakan sebagai bahan penelitian adalah larutan dengan kepekatan sekitar $15 \% \mathrm{Cu}$, sehingga untuk mensetarakan jumlah tembaga terlarut dalam limbah cair dengan larutan kontrol maka dilakukan pengambilan limbah cair pekat $\left(\mathrm{CuCl}_{2}\right)$ sebanyak $590,55 \mathrm{ml}$. Asam Sulfat $\left(\mathrm{H}_{2} \mathrm{SO}_{4}\right)$ $202,86 \mathrm{gr} / \mathrm{L}$; Aquadest 299,2 ml/L ; Kondisi Operasi : Temperatur $25-30{ }^{\circ} \mathrm{C}$; Agitasi ; Filterisasi ; $\mathrm{pH} 1$; Voltase 7 volt.

Jika larutan limbah cair sisa proses etching tersebut diencerkan hingga volume 1 liter maka kandungan tembaga terlarut dalam limbah akan berubah setara dengan 88,58 gram $\mathrm{Cu}$. Untuk mencapai kondisi yang setara dengan larutan kontrol A ; kontrol B dan kontrol $\mathrm{C}$ maka dilakukan penambahan $\mathrm{H}_{2} \mathrm{SO}_{4}$. Dimana limbah cair yang disetarakan tersebut 
diberi kode $\mathrm{A}^{\prime}, \mathrm{B}^{\prime}, \mathrm{C}^{\prime}$. Penambahan $\mathrm{H}_{2} \mathrm{SO}_{4}$ tersebut sebanyak $67,5 \mathrm{gr} / \mathrm{L}$ untuk larutan elektrolit A'; 331,8 gr/L untuk larutan elektrolit B' dan 414,7 gr/L untuk larutan elektrolit C'. Seluruh larutan elektrolit kontrol $A$; kontrol $B$; kontrol $C$; $A^{\prime}$; $B^{\prime}$ dan $C^{\prime}$ selanjutnya disiapkan dalam kondisi homogen dengan proses agitasi secara terus menerus.

Penyiapan terhadap benda kerja dilakukan dengan proses degreasing dan pickling. Proses ini bertujuan untuk menghilangkan berbagai kotoran yang menempel pada permukaan benda kerja dan berpotensi dapat menggagalkan proses pelapisan logam. Proses degreasing / penghilangan minyak dan lemak dilakukan dengan membersihkan permukaan benda kerja dengan larutan alkali $(\mathrm{NaOH})$ sementara proses pickling dilakukan dengan larutan Asam sulfat $\left(\mathrm{H}_{2} \mathrm{SO}_{4}\right)$.

Sebelum proses elektroplating, maka akan dilakukan penimbangan pada benda kerja. Benda kerja yang digunakan dalam penelitian ini adalah pelat besi dengan ketebalan $2 \mathrm{~mm}$. Pengerjaan proses elektroplating akan terbagi atas proses elektroplating benda kerja dengan larutan tembaga sulfat $\left(\mathrm{CuSO}_{4}\right)$ sebagai kontrolnya dan proses elektroplating benda kerja dengan larutan limbah cair sisa proses etching PCB $\left(\mathrm{CuCl}_{2}\right)$. variabel durasi plating selama 30 detik, 60 detik dan 90 detik. Jumlah Asam sulfat yang ditambahkan sebanyak 45 ; 60 ; $90 \mathrm{gr} / \mathrm{L}$. Sesudah proses elektroplating, maka dilakukan proses pelapisan dan penimbangan. Prosentase penambahan bobot akan dihitung dari selisih berat benda kerja dan berat hasil elektroplating yang kemudian dapat dianalisis melalui grafik korelasi durasi pelapisan terhadap prosentase penambahan. Selain itu dilakukan pula pengamatan visual terhadap hasil elektroplating untuk menentukan hasil yang terbaik.

\section{HASIL DAN PEMBAHASAN}

Langkah awal adalah pengujian limbah cair sisa etching PCB dan hasil analisanya dapat dilihat pada tabel 1. Dimana, dapat dilihat bahwa limbah cair sisa proses etching PCB tidak hanya mengandung unsur tembaga $(\mathrm{Cu})$ saja, namun mengandung unsur lain dengan konsentrasi tinggi yaitu Besi (Fe) dengan kadar hingga 234,8 mg/L sementara kadar Seng (Zn) sekitar 10,01 mg/L. Sedangkan penelitian yang dilakukan oleh Anggrainy et al. (2018) mengungkap bahwa limbah cair proses etching PCB mengandung logam berat tembaga (Cu) sebesar 1,55 \% atau $15.500 \mathrm{mg} / \mathrm{l}$. Arini, et al. (2017) juga memperoleh hasil kandungan limbah cair industri PCB terdiri atas $7579 \mathrm{mg} / \mathrm{l} \mathrm{Cu}, 0,330 \mathrm{mg} / \mathrm{l} \mathrm{Cr}$ Total, 31,16 mg/l Fe dan $\mathrm{pH}$ 1. Bila dibandingkan maka hasil uji penelitian tersebut jauh beda dengan hasil karakteristik limbah industri etching yang akan digunakan dalam penelitian ini dikarenakan limbah yang akan digunakan adalah limbah cair yang telah jenuh, pekat dan telah tersimpan untuk beberapa lama.

Tabel 1. Karakteristik limbah cair sisa etching PCB

\begin{tabular}{clcc}
\hline No. & \multicolumn{1}{c}{ Parameter } & Hasil uji & Satuan \\
\hline 1. & Tembaga $(\mathrm{Cu})$ & 15,10 & $\%$ \\
\hline 2. & Seng $(\mathrm{Zn})$ & 10,01 & $\mathrm{mg} / \mathrm{L}$ \\
\hline 3. & Krom $(\mathrm{Cr})$ & 0,93 & $\mathrm{mg} / \mathrm{L}$ \\
\hline 4. & Timbal $(\mathrm{Pb})$ & 0,1 & $\mathrm{mg} / \mathrm{L}$ \\
\hline 5. & Kadmium $(\mathrm{Cd})$ & $<0,001$ & $\mathrm{mg} / \mathrm{L}$ \\
\hline 6. & Besi $(\mathrm{Fe})$ & 234,8 & $\mathrm{mg} / \mathrm{L}$ \\
\hline 7. & TDS & 100,12 & $\mathrm{mg} / \mathrm{L}$ \\
\hline 8. & Nikel $(\mathrm{Ni})$ & Tidak ternyata \\
\hline 9. & Densitas cairan & \multicolumn{2}{c}{1,169} \\
\hline 10. & Angka keasaman $(\mathrm{pH})$ & \multicolumn{2}{c}{$<1$} \\
\hline
\end{tabular}

Angka keasaman yang sangat rendah pada limbah cair ini berasal dari ionisasi sempurna larutan $\mathrm{HCl}$ yang digunakan sebagai larutan etching papan $\mathrm{PCB}$. pH yang sangat rendah dan tingginya kandungan tembaga terlarut sangat sesuai dengan karakteristik 
larutan sebagai larutan elektrolit. Setelah dilakukan proses elektroplating tembaga dengan berbagai variabel sesuai dengan metodologi penelitian dan dilakukan penimbangan berat hasil benda kerja $A, B, C, A^{\prime}, B^{\prime}$, dan $C^{\prime}$ maka akan dihitung prosentase penambahan berat. Kemudian hasil yang diperoleh digambarkan dalam grafik hubungan durasi proses pelapisan terhadap penambahan bobot lapisan pada benda kerja seperti pada gambar 1 berikut.

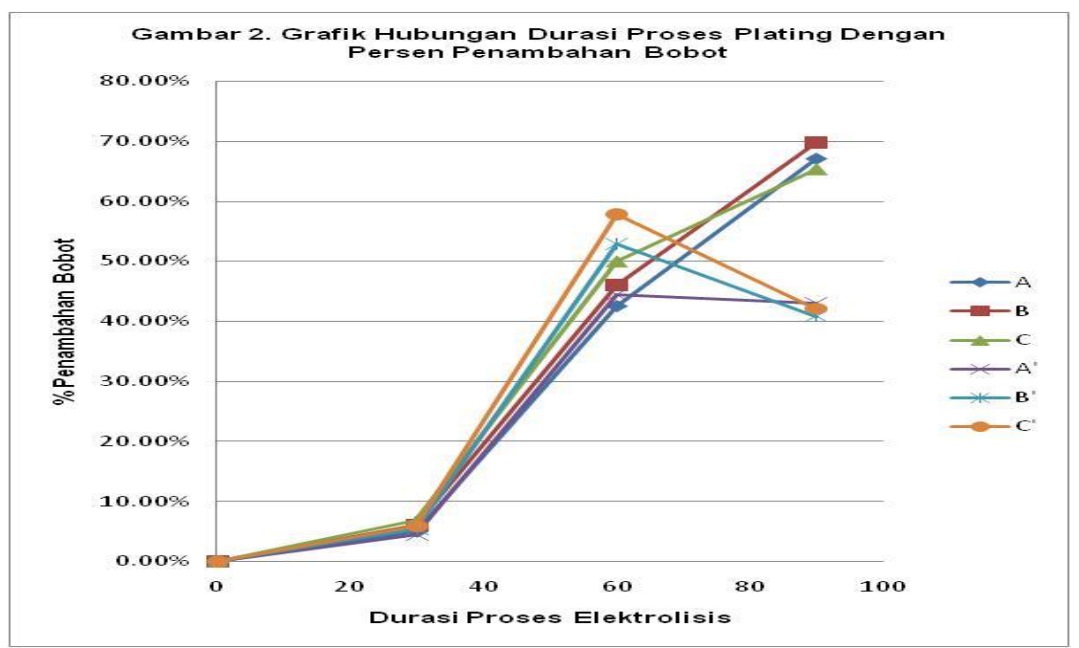

Gambar 1. Grafik korelasi antara durasi proses pelapisan (detik) terhadap persentase (\%) penambahan bobot lapisan.

Dari gambar 1 di atas dapat diamati bahwa terjadi penambahan bobot / massa benda kerja yang juga berkorelasi dengan penambahan bobot lapisan benda kerja setelah proses pelapisan (elektrodeposisi) dilangsungkan. Semakin lama benda kerja dielektrolisis maka bobot benda kerja juga semakin bertambah karena terdapat deposit / endapan logam pada permukaannya. Sesuai dengan hukum faraday 1 yang menyatakan Massa zat yang dihasilkan pada elektrode berbanding lurus dengan massa ekivalen zat, maka dalam penelitian ini banyaknya endapan yang terbentuk pada katoda sangat ditentukan oleh durasi proses elektrolisis serta besarnya arus listrik yang digunakan untuk proses elektrolisis. Bobot lapisan logam yang terbentuk (gram) berbanding lurus dengan durasi proses pelapisan (detik) dan arus listrik yang digunakan (Topayung, 2011).

Namun hasil penimbangan benda kerja setelah proses pelapisan pada detik ke 90 menunjukkan penurunan penambahan bobot lapisan deposit tembaga jika dibandingkan pada perlakuan sebelumnya. Hal ini dimungkinkan karena terjadi perubahan konsentrasi larutan dimana konsentrasi larutan elektrolit tembaga semakin berkurang per satuan waktu karena sebagian kation tembaga $\left(\mathrm{Cu}^{2+}\right)$ telah tereduksi pada pelat besi / benda kerja. Sementara itu angka keasaman larutan elektrolit juga telah mengalami perubahan yaitu yang semula menunjukkan $\mathrm{pH}$ kisaran 0-1 naik menjadi $\mathrm{pH}$ kisaran 2-3. Hal ini dikarenakan ion $\mathrm{H}^{+}$dari larutan (asam) telah berubah dan lepas menjadi gas $\mathrm{H}_{2}$ sehingga angka keasaman larutan menjadi berkurang.

Perubahan konsentrasi larutan elektrolit ini berlangsung secara merata, artinya tidak hanya terjadi disekitar anoda dan katoda karena sepanjang proses elektrolisis dilakukan agitasi. Tujuan agitasi pada proses electrolisis ini adalah untuk memeratakan jumlah kation dalam larutan elektrolit. Hal ini karena larutan yang berdekatan dengan katoda akan mengalami defisit kation manakala tidak dilakukan proses agitasi.

Hasil pengamatan visual terhadap produk hasil elektrolisis pada berbagai macam formulasi dapat dilihat pada tabel berikut. 
Tabel 2. Hubungan formulasi larutan elektrolit terhadap durasi proses plating.

\begin{tabular}{|c|c|c|c|c|c|c|}
\hline \multirow{3}{*}{$\begin{array}{c}\text { Kode } \\
\text { formulasi }\end{array}$} & \multicolumn{6}{|c|}{ Durasi plating } \\
\hline & \multicolumn{2}{|c|}{30 detik } & \multicolumn{2}{|c|}{60 detik } & \multicolumn{2}{|c|}{90 detik } \\
\hline & Warna & Kerekatan & Warna & Kerekatan & Warna & Kerekatan \\
\hline Kontrol A & Cerah & Baik & Cerah & Baik & Cerah & Terkelupas \\
\hline $\mathbf{A}^{\prime}$ & Tidak cerah & Baik & Tidak cerah & Baik & Tidak cerah & Terkelupas \\
\hline Kontrol B & Cerah & Baik & Cerah & Baik & Cerah & Terkelupas \\
\hline $\mathbf{B}^{\prime}$ & Tidak cerah & Baik & Tidak cerah & Baik & Tidak cerah & Terkelupas \\
\hline Kontrol C & Cerah & Baik & Cerah & Baik & Cerah & Terkelupas \\
\hline $\mathbf{C}^{\prime}$ & Tidak cerah & Baik & Tidak cerah & Baik & Tidak cerah & Terkelupas \\
\hline
\end{tabular}

Pada gambar $2 \mathrm{~s} / \mathrm{d}$ gambar 4 di bawah ini menunjukkan beberapa hasil akhir proses electroplating terhadap benda kerja dengan menggunakan larutan elektrolit kontrol $\left(\mathrm{CuSO}_{4}\right.$ teknis).

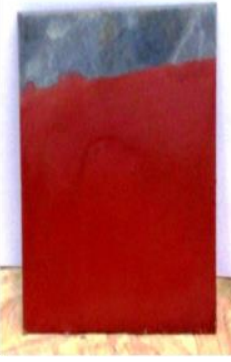

Formulasi control $\mathrm{A}$

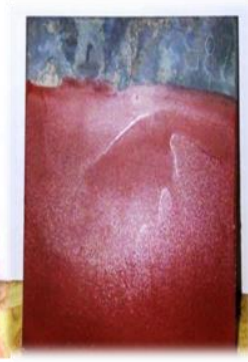

Formulasi control B

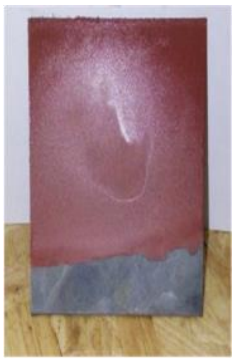

Formulasi control B

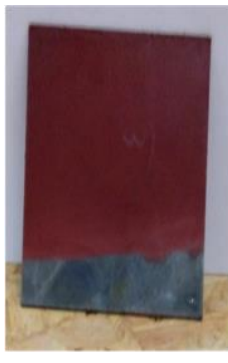

Formulasi control C

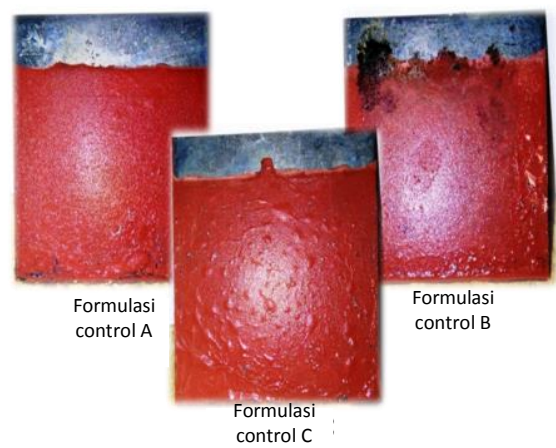

Gambar 4. Produk pelapisan dengan larutan kontrol dengan durasi 90 detik

Gambar 2. Produk pelapisan
dengan larutan kontrol dengan durasi 30 detik
Gambar 3. Produk pelapisan dengan larutan control dengan durasi 60 detik

Dapat dilihat dengan jelas bahwa produk pelapisan dengan menggunakan larutan elektrolit $\mathrm{CuSO}_{4}$ teknis dengan durasi proses pelapisan yang singkat (30 detik) mampu memberikan hasil yang cukup baik, hasil ini dapat dipertahankan hingga durasi proses mencapai 60 detik. Lapisan tembaga mampu merekat dengan baik, tidak ada indikasi atau spot yang hendak terkelupas, demikian juga dengan ketebalan lapisan yang tampak sama dan rata, warna lapisan juga tampak cerah.

Sementara itu produk pelapisan dengan menggunakan larutan elektrolit menggunakan limbah cair sisa proses etching PCB dengan dengan durasi proses selama 30 detik s/d 90 detik ditunjukkan pada gambar $5 \mathrm{~s} / \mathrm{d}$ gambar 7 dibawah ini.

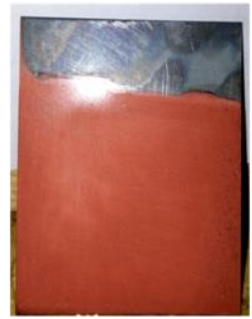

Formulasi $A^{\prime}$

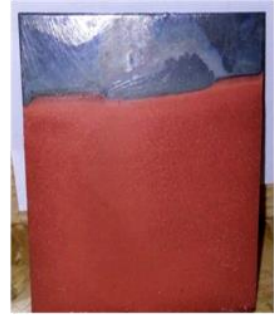

Formulasi B'

Gambar 5. Produk pelapisan dengan larutan dari limbah cair etching dengan durasi plating selama 30 detik

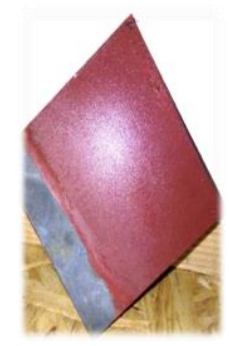

Dari Formulasi i

Gambar pelapisan dengan larutan dari limbah cair etching dengan durasi plating selama 60 detik

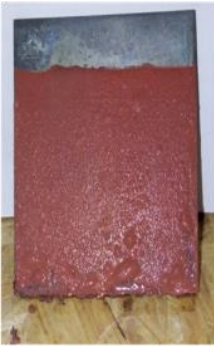

Formulasi $A^{\prime}$

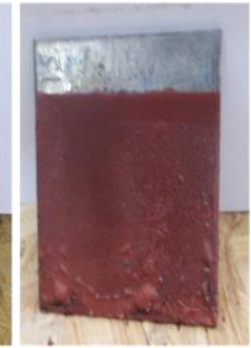

Formulasi B'
Gambar 7. Produk pelapisan dengan larutan dari limbah cair etching dengan durasi plating selama 90 detik 
Dari gambar $5 \mathrm{~s} / \mathrm{d}$ gambar 7 dapat dilihat bahwa lapisan tembaga yang menutup permukaan benda kerja tampak 2 perbedaan mencolok antara yang dielektrolisis selama 30 dan 60 detik serta selama 90 detik. Pada proses elektrolisis dengan durasi 30 dan 60 detik lapisan tembaga dari elektrolit limbah cair sisa proses etching PCB tampak merekat sempurna, tidak ada bagian / spot yang berpotensi akan terkelupas. Lapisan tembaga yang merekat pada permukaan benda kerja bahkan mampu menutup goresan-goresan halus pada benda kerja yang memang mengalami cacat bahan.

Namun hasil yang berbeda ditunjukkan pada gambar 7 yaitu produk penelitian dengan menggunakan larutan elektrolit limbah cair dengan durasi proses diperpanjang hingga 90 detik. Tampak beberapa spot pada permukaan benda kerja mengalami penggembungan lapisan yang menunjukkan bahwa lapisan berpotensi dapat terkelupas.

Terkelupasnya lapisan plating dari permukaan benda yang dilapis pada saat dilaksanakan proses plating kemungkinan disebabkan oleh terdapatnya kotoran atau lapisan minyak pada permukaan benda yang dilapis. Hal ini dapat dilihat pada tabel 2 bahwa pada seluruh perlakuan (kontrol $A, A^{\prime}$, kontrol $B, B^{\prime}$, kontrol $C$ dan $C^{\prime}$ ) untuk durasi plating 90 detik seluruhnya mengalami hal yang sama yaitu lapisan terkelupas. Hal ini kemungkinan dipengaruhi oleh berkurangnya kemampuan larutan alkali atau pickle. Larutan alkali maupun larutan pickle yang digunakan merupakan sisa larutan yang telah digunakan untuk kelompok sebelumnya ( variabel benda kerja 30 dan 60 detik) dan bukan larutan baru. Warna permukaan benda kerja yang dilakukan plating dengan larutan elektrolit yang berasal dari limbah cair proses etching PCB (kelompok $A^{\prime}, B^{\prime}$ dan $C^{\prime}$ ) tampak lebih kusam / sedikit kecoklatan dan kurang cerah jika dibandingkan dengan produk benda kerja yang dielektrolisis dengan larutan kontrol / $\mathrm{CuSO}_{4}$ teknis (Kontrol A, Kontrol B dan Kontrol C).

Perbedaan warna juga terlihat jelas pada larutan elektrolit dimana seluruh larutan control ( $A, B$ dan $C$ ) memiliki warna yang biru cerah dan tampak jernih namun untuk larutan elektrolit $A^{\prime}$; $B^{\prime}$ dan $C^{\prime}$ memiliki warna biru dengan sedikit warna coklat dan tidak secerah larutan control. Gambar berikut menunjukkan masing-masing warna larutan elektrolit.

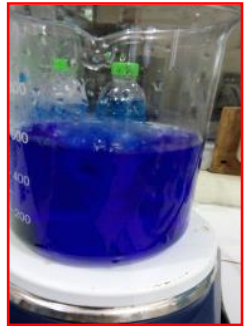

(a)

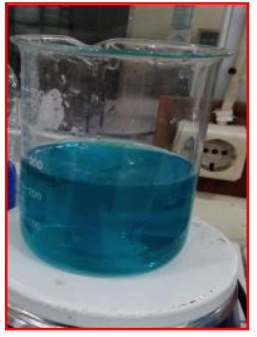

(b)

Gambar 8. Perbedaan warna larutan larutan kontrol dan larutan limbah etching (a) larutan elektrolit kontrol / $\mathrm{CuSO}_{4}$ teknis (b) limbah etching PCB

Perbedaan warna larutan elektrolit tersebut dikarenakan bahwa pada larutan elektrolit dari limbah cair sisa proses etching PCB terpapar unsur besi yang cukup tinggi (larutan induk limbah cair mengandung besi sekitar $234,8 \mathrm{mg} / \mathrm{L}$ ) sehingga pada Larutan $\mathrm{A}^{\prime}$ mengandung unsur besi sekitar $138,65 \mathrm{mg} / \mathrm{L}$ yang mengakibatkan warna biru larutan tidak setajam larutan $\mathrm{CuSO}_{4}$ teknis atau larutan control yang hanya mengandung unsur besi maksimal 0,445 mg/L.

\section{KESIMPULAN}

Larutan limbah cair sisa proses etching PCB berpotensi untuk digunakan sebagai larutan elektrolit pada elektroplating dengan benda kerja dari besi dimana kandungan 
tembaga yang terlarut dalam limbah tersebut $15 \%(150 \mathrm{~g} / \mathrm{l})$. Dengan menggunakan variabel waktu 30 detik, 60 detik dan 90 detik maka benda kerja dapat terlapisi oleh tembaga yang berasal dari limbah cair etching dengan ditunjukkan oleh adanya penambahan bobot. Namun pada durasi plating 90 detik memberikan keretakan pada benda kerja. Warna lapisan tembaga yang dimunculkan untuk seluruh perlakuan dengan bahan limbah cair tidak secerah warna yang dimunculkan oleh larutan control $\left(\mathrm{CuSO}_{4}\right)$. Dari produk yang terlapisi, maka kondisi terbaik adalah dengan penambahan $\mathrm{H}_{2} \mathrm{SO}_{4}$ sebesar $414,7 \mathrm{gr} / \mathrm{L}$ dan durasi plating 60 detik sehingga penambahan bobot hampir $60 \%$ dan tidak terkelupas.

\section{UCAPAN TERIMAKASIH}

Ucapan terimakasih disampaikan pada Ka.Baristand Industri Surabaya, Kasi Teknologi Industri dan Rekan-rekan Tim Peneliti dan Rekan-rekan di Laboratorium Uji di Baristand Industri Surabaya yang telah memberikan dukungan hingga selesainya penelitian dan artikel ini.

\section{DAFTAR PUSTAKA}

Anonim. 2012. Printed Circuit Board Recycling Methods. Workshop Materials on WEEE Management in Taiwan. 10 Oktober 2012. 1-10

Anggrainy Pascalia Shendy, Jati Nugroho A.W, dan Murwani Indah. 2018, Pemanfaatan Bakteri Indigenus dalam Reduksi Logam Berat $\mathrm{Cu}$ Pada Limbah Cair Proses Etching Printed Circuit Board (PCB), Biota Vol.3 (2): 87-95, Juni 2018

Arini., et all. 2017. Reduksi Kadar Tembaga (Cu) Dengan Metode Elektrolisis Pada Pengolahan Limbah Cair Priting Circuit Board (PCB). Jurnal Sumber Daya Alam dan Lingkungan.Vol 4. No.2. Universitas Brawijaya

Azhar A. Saleh. 2011. Modul Diklat : Teknik Pelapisan Tembaga. Balai Besar Pengembangan Industri Logam dan Mesin.

Cahyono Bowo Handaru dan Mahmida nurul. 2014. Reduksi Tembaga Dalam Limbah Cair Proses Etching Printing Circuit Board (PCB) Dengan Proses Elektrokimia. Jurnal Riset Industri Vol. 8 No. 2. Agustus 2014. Hal $101-121$.

Rice, E.W., Birdi, R. B., dan Eaton,A.D. 2017. Standard Methods for Examination of Water and Wastewater, 23rd edition, American Water Works Association. United States

Haughn M. 2013. Printed Circuit Board. http://www.whatis.techtarget.com/ definition/printed-circuit-board-PCB. 6 April 2017 (10:02).

Luda Maria paola. 2011. Recycling of Printed Circuit Boards. Integrated Waste Management Volume II. INTECH Publisher. 285-298

Lou Helen dan Yinlun Huang. 2006. Electroplating. Encyclopedia of Chemical processing. Taylor \& Francis. New York. 1-10

Mustopo Dwi Y. 2011. Pengaruh waktu terhadap ketebalan dan adhesivitas lapisan proses electroplating krom dekoratif tanpa lapisan dasar, dengan lapisan dasar tembaga dan tembaga-nikel. Skripsi. Jurusan Teknik Mesin. Universitas Sebelas Maret. Surakarta.

Myers Joshua. 2011. A Process of Chemically Etching Circuit Boards Application Note. Michigan State University. East Lansing. Hand Books Texas Instruments. 3-11

Ridho. 2014. Market Brief: Peluang Ekspor Komponen Elektronik ke Pasar Taiwan. www.djpen.kemendag.go.id/membership/data/files/ecc45-komponen-elektronik.pdf. 20 Juni 2017 (12:49).

P. Purwanto, S. Rukiyawati, dan A.Purbasari. 2017. Elektroplating Tembaga pada Baja Menggunakan Elektrolit Asam Lemah. Jurnal Reaktor. vol. 3, no. 1. 22-25

Topayung Daud. 2011. Pengaruh Arus Listrik Dan Waktu Proses Terhadap Ketebalan dan Massa lapisan Yang Terbentuk Pada Proses Electroplating Pelat Baja. Jurnal Ilmiah Sains Vol 11, No.1. April 2011. 97-101 